\title{
Millennial Leaner Scaffolding Needs: A Comparative Study at STKIP Saint Paul Ruteng, Flores, Indonesia
}

\author{
$1^{\text {st }}$ Hendrikus Midun \\ STKIP Saint Paul Ruteng \\ Flores Indonesia \\ hendrik.m2002@gmail.com \\ $2^{\text {nd }}$ I Nyoman S. Degeng \\ State Univerity of Malang \\ Malang, Indonesia
}

\author{
$3^{\text {rd }}$ Dedi Kuswandi \\ State Univerity of Malang \\ Malang, Indonesia \\ $4^{\text {th }}$ Saida Ulfa \\ State Univerity of Malang \\ Malang, Indonesia
}

\begin{abstract}
Millennial learners have different ways of working from the previous generation. The main thing that distinguishes them from previous generations is that they are very familiar with the internet as a learning medium. However, millennial learners have problems, such as learning control, learning disorientation, and cognitive burdens for students. This study aims to determine the differences in the scaffolding needs of millennial students based on the length of study at tertiary institutions. This study involved 156 students. They consist of second, fourth and sixth-semester students. The research instrument used a questionnaire. By the ANOVA analysis it is concluded: (1) there is a significant difference in the scaffolding needs of millennial students based on the length of study in tertiary institutions. (2) The higher the semester level, the more students don't need scaffolding. Based on this conclusion some suggestions are (1) it is necessary to experiment about the differences in the needs and urgency of scaffolding for millennial students, both in college, elementary, middle / secondary, and secondary; (2) need to use scaffolding-based student needs forms; and (3) learning analysis needs to be done, related to students' learning needs before determining and using scaffolding in learning activities.
\end{abstract}

Keywords: scaffolding, google, millennial learners, online, net generation

\section{INTRODUCTION}

One of the effects of advances in modern information and communication technology is the change in student learning habits. They do online and digital learning activities. With Google, they search and collect information faster, more flexible, and richer [1]. Millennial students learn independently with the learning methods and strategies they want. Even so, previous research found that learning using google and/or online in the millennial era was not without problems. Studied by Hsieh, Lee, and Su found that the learning system of google or online learning causes three probes: learning control, learning disorientation, and cognitive load for students [2].

This dichotomous reality can create pedagogical dilemmas for teachers and educational institutions. On the one hand, the presence of modern communication media (such as smartphones) makes it easy for students to learn independently, and reduces teaching hours in class [1] [3]. The use of gadgets can give birth to innovative learning models and prepare millennial students to adapt to the development of modern information and communication technology. Kamdi has explained that $35 \%$ of core skills will be lost by $2025,65 \%$ of elementary students will get jobs that do not yet exist, and around 14.2 million workers can migrate between ASEAN countries (Kompas, 3 March 2018) [4].

On the other hand, the use of gadgets can reduce the reading habits of millennial students. The NEA (National Endowment for the Arts) report on reading in America in 2004 revealed that there was a $10 \%$ decline in millennial generation reading activities; Although they collect information through digital, but they do not read what they have collected [5]. Research by Jeffery S. Thomas and Timothy A. Philpot about implementing an inverted classroom strategy reveals that there is no difference in learning outcomes between students in inverted and conventional classes [6].

This fact encourages teachers and lecturers to seek the scaffolding needed by millennial students. Scaffolding is an induction process that stimulates cognitive, metacognitive, motivational, and/or cooperative activities during learning in various forms [7]. Therefore this study aims to answer two questions. First, are there differences in millennial student scaffolding needs based on the length of study in college? Second, what form of scaffolding do millennial students need? 
the achievement of procedural abilities [12]. However, many forms of scaffolding can answer many student learning needs [11]. Belland, Glazewski, and Richardson found that scaffolding can support the development of student argumentation skills [13].

Scaffolding is a technique or induction process that stimulates cognitive, metacognitive, motivational, and/or cooperative activities during learning, in various forms [7]. Scaffolding is mainly given to students who do not have prior knowledge (in the material to be taught) and have low academic achievement [11]. That way the scaffolding provided is based on needs. With needs-based, scaffolding will achieve ZPD (Zone of Proximal Development) conditions according to Vygotsky [14], guiding independent learning [15], and achieving learning success for students [16].

To achieve this orientation, scaffolding has various forms, such as hints, feedback, instructing, modeling, questioning, suggesting, encouraging problems, and a reminder to conduct learning activities independently [7] [17] [18] [19]. Determination and use of scaffolding forms are very dependent on the characteristics of students.

Scaffolding can be given by a teacher or lecturer, parents, peer in the form of computer-based or paper-based tools that enable students to participate meaningfully in learning and experience skills in tasks that they cannot achieve independently [17] [20]. This is very necessary, especially when they do online learning as revealed in the research of Wang [21]. In the context of online learning, scaffolding in self-regulated learning (SRL) is very important for knowledge maps, discussions, questions and answers about the concept of knowledge, and online chat for conceptual understanding and content [21]. Expert guidance in the form of road maps and strategies given to student learning environments can help them understand the discipline of the investigation process [22].

Online learning (learning via google), for example, inverted classroom learning strategies will be effective and efficient using scaffolding [23] [24] [25]. Because this strategy requires learning assistance from other parties [26], especially in online learning sessions, in the form of questionnaires and worksheets [25], instructions, feedback and instruct so that students can do learning activities with easy and smooth [17].

\section{METHODS}

This research uses a comparative study. Researchers compared the needs of scaffolding students based on the length of study in college. The research method used was a survey. This research was conducted at the Indonesian Language Study Program STKIP Santu Paulus Ruteng, Flores Indonesia. The research subjects were 156 students, including the second semester, fourth semester, and sixth-semester students. Each semester consists of 52 students. The determination of the research subject is clustered. Determining the subject of three 
because the significance value $(0.125)$ is greater than the alpha $(0.05)$ as shown in Table 2.

\section{TABLE II. TEST OF HOMOGENEITY OF VARIANCES}

Data collection instruments use questionnaires. Through questionnaires, the researchers wanted to find out the needs of student scaffolding and forms of scaffolding that they needed as millennial students. Before being used, the research instrument is tested for validity with the aim to ensure that the instrument has the ability to actually measure what should be measured [27]. Validity test results using guidelines made by [28]. According to Pallant, the instrument is considered valid if it has a correlation coefficient ( $r$ ) of each item greater than 0.3 [28]. Besides the validity test, the instrument also carried out reliability testing, to ensure that the instrument used had a good level of consistency as a measuring instrument [27]. The reliability test of this study uses Alpha's Cronbach with the Cronbach coefficient value $>0.7$ [29]. The results of the questionnaire data were analyzed using descriptive analysis techniques. Furthermore, to see the difference in student scaffolding needs every semester, one-way ANOVA (Analysis of Variance) analysis is used.

\section{RESUlTS AND DISCUSSION}

The forms of scaffolding asked to respondents include hints, feedback, instructing, modeling, questioning, suggesting, encouraging, and reminder [7] [17] [18] [19]. Each question or statement item consists of five options, namely: 1) very dislike, 2) dislike, 3) enough likes, 4) likes, 5) really likes. The results of the descriptive analysis are shown in Table 1.

TABLE I. DESCRIPTIVE ANALYSIS

\begin{tabular}{|c|c|c|c|c|c|c|c|c|}
\hline \multirow[t]{2}{*}{$\begin{array}{l}\text { Descriptives } \\
\text { Scaffolding } \\
\text { Semester }\end{array}$} & \multirow[t]{2}{*}{$\mathrm{N}$} & \multirow[t]{2}{*}{ Mean } & \multirow[t]{2}{*}{$\begin{array}{l}\text { Std. } \\
\text { Deviation }\end{array}$} & \multirow[t]{2}{*}{$\begin{array}{l}\text { Std. } \\
\text { Error }\end{array}$} & \multicolumn{2}{|c|}{$\begin{array}{l}95 \% \text { Confidence } \\
\text { Interval for Mean }\end{array}$} & \multirow[t]{2}{*}{ Min. } & Max. \\
\hline & & & & & $\begin{array}{l}\text { Lower } \\
\text { Bound }\end{array}$ & $\begin{array}{l}\text { Upper } \\
\text { Bound }\end{array}$ & & \\
\hline 2 & 52 & 33.42 & 3.522 & .488 & 32.44 & 34.40 & 26 & 40 \\
\hline 4 & 52 & 32.58 & 3.392 & .470 & 31.63 & 33.52 & 25 & 40 \\
\hline 6 & 52 & 31.67 & 3.405 & .472 & 30.73 & 32.62 & 25 & 39 \\
\hline TOT & 156 & 32.56 & 3.492 & .280 & 32.01 & 33.11 & 25 & 40 \\
\hline
\end{tabular}

Based on Table 1, it can be stated that: (1)Tthe lowest score of the fourth and sixth-semester students is 25 and the secondsemester students are 26. (2) The highest score of second and fourth-semester students are 40 and sixth-semester students are 39. (3) There are differences in grades on average between the second semester, the fourth semester, and sixth-semester students. The difference in mean scores between second and fourth-semester students is 0.8 , the fourth semester and the sixth semester is 0.91 , and between the second semester and sixthsemester students is 1.77. (4) There is a tendency that the higher the semester, the lower the acquisition of the average scaffolding needs.

To determine the significance of differences in student scaffolding needs based on semester, one-way ANOVA analysis was carried out. ANOVA analysis is carried out after the test of homogeneity of variances shows the data is homogeneous

\begin{tabular}{|c|c|c|c|}
\hline \multicolumn{4}{|c|}{$\begin{array}{l}\text { Test of Homogeneity of Variances } \\
\text { Scaffolding }\end{array}$} \\
\hline Levene Statistic & df1 & df2 & Sig. \\
\hline .092 & 2 & 153 & .912 \\
\hline
\end{tabular}

The statistical hypothesis is:

$\mathrm{H} 0$ : there is no significant difference in the needs of second, fourth and sixth-semester student scaffolding.

H1: there are significant differences in the needs of scaffolding for second, fourth and sixth-semester students.

Statistical test results show that the calculated F-value is 3.365 while the F-table value at df $1=2$ and df $2=153$ is 3.055 . This is shown in Table 3.

TABLE III. ANOVA

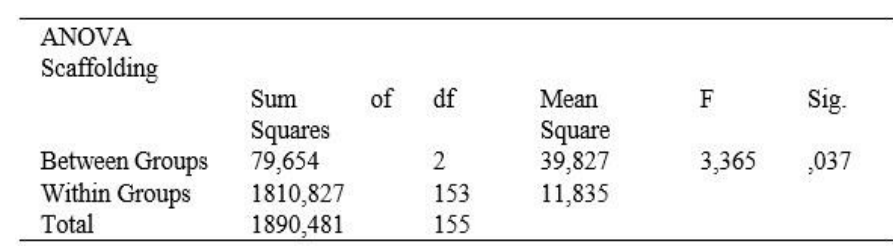

Table 3 shows that the F-count value is greater than F-table $(3.365>3.055)$ and the significance value $(\mathrm{P}=0.037)$ is smaller than the alpha (0.05). Therefore we can conclude that HO is rejected and $\mathrm{H} 1$ is accepted. This means that there are significant differences in scaffolding needs between second, fourth and sixth-semester students.

To see the difference in student scaffolding needs between semesters $(2,4,6)$, the Post Hoc Test was conducted. Post hoc test results are shown in Table 4.

TABLE IV. TeST Post Hoc

\begin{tabular}{|c|c|c|c|c|c|c|c|}
\hline \multicolumn{8}{|c|}{$\begin{array}{l}\text { Multiple Comparisons } \\
\text { Dependent Variable: Scaffolding } \\
\text { Scheffe }\end{array}$} \\
\hline \multirow{2}{*}{$\begin{array}{l}\text { Scheffe } \\
\text { (I) } \\
\text { Semester }\end{array}$} & \multirow{2}{*}{$\begin{array}{l}\text { (J) } \\
\text { Semester }\end{array}$} & \multirow{2}{*}{$\begin{array}{l}\text { Mean } \\
\text { (I-J) }\end{array}$} & \multirow{2}{*}{ Difference } & \multirow{2}{*}{$\begin{array}{l}\text { Std. } \\
\text { Error }\end{array}$} & \multirow[t]{2}{*}{ Sig. } & \multicolumn{2}{|c|}{ 95\% Confidence Interval } \\
\hline & & & & & & Lower Bound & Upper Bounc \\
\hline \multirow[t]{2}{*}{2} & 4 & 846 & &, 675 & ,457 &,- 82 & 2,51 \\
\hline & 6 & $1,750^{*}$ & & 675 &, 037 &, 08 & 3,42 \\
\hline \multirow[t]{2}{*}{4} & 2 &,- 846 & & 675 & ,457 & $-2,51$ & 82 \\
\hline & 6 & 904 & & 675 & 410 &,- 76 & 2,57 \\
\hline \multirow[t]{2}{*}{6} & 2 & $-1,750^{*}$ & & 675 &, 037 & $-3,42$ &,- 08 \\
\hline & 4 &,- 904 & &, 675 & 410 & $-2,57$ &, 76 \\
\hline \multicolumn{8}{|c|}{ *. The mean difference is significant at the 0.05 level. } \\
\hline
\end{tabular}

Based on Table 4 it can be said that there are significant differences in scaffolding needs between second and sixthsemester students, wherein the significance value (sig. 0.037) is smaller than the alpha value $(0.05)$. Whereas between the second and fourth-semester students there was no significant difference 
in scaffolding needs because the significance value (sig. 0.457) was greater than the alpha value $(0.05)$. Likewise, between fourth and sixth-semester students, there was no significant difference in scaffolding requirements because the significance value (sig. 0.410) was greater than the alpha value (0.05). Based on the significance of each semester, it can be said that first semester students have higher scaffolding needs than fourth and sixth-semester students; fourth-semester students have higher scaffolding needs than sixth-semester students.

When respondents (students) were asked, which form of scaffolding do you need most? They have varied answers. This can be shown in Table 5 .

TABLE V. SCAFFOLDING IS NEEDED

\begin{tabular}{|c|c|c|c|c|c|c|c|c|}
\hline Smtr & Hints & Feedback & Instructing & Modeling & Quetioning & Suggesting & Encourage & Reminder \\
\hline \multirow[t]{2}{*}{2} & 8 & 4 & 3 & 15 & 9 & 4 & 4 & 5 \\
\hline & $\begin{array}{l}15,4 \\
\%\end{array}$ & $7,7 \%$ & $5,8 \%$ & $28,8 \%$ & $17,3 \%$ & $7,7 \%$ & $7,7 \%$ & $9,6 \%$ \\
\hline \multirow[t]{2}{*}{4} & 13 & 3 & 2 & 13 & 5 & 7 & 3 & 6 \\
\hline & $25 \%$ & $5,8 \%$ & $3,8 \%$ & $25 \%$ & $9,6 \%$ & $13,5 \%$ & $5,8 \%$ & $11,5 \%$ \\
\hline \multirow[t]{2}{*}{6} & 12 & 1 & 0 & 20 & 7 & 5 & 2 & 5 \\
\hline & $\begin{array}{l}23,1 \\
\%\end{array}$ & $1,9 \%$ & $0 \%$ & $38,5 \%$ & $13,5 \%$ & $9,6 \%$ & $3,8 \%$ & $9,6 \%$ \\
\hline \multirow[t]{2}{*}{ TOT } & 33 & 8 & 5 & 48 & 21 & 16 & 9 & 16 \\
\hline & $\begin{array}{l}21,2 \\
\%\end{array}$ & $5,1 \%$ & $3,2 \%$ & $30,8 \%$ & $13,5 \%$ & $10,3 \%$ & $5,8 \%$ & $10,3 \%$ \\
\hline
\end{tabular}

Based on Table 5 it can be explained: First, the most needed form of scaffolding is modeling (30.8\%) although the percentage of each semester varies (second-semester students $28.8 \%$, fourth-semester students $25 \%$, and sixth-semester students $38 \%$ ). While the least needed form of scaffolding is the instructing, because it has the lowest percentage (3.2\%) among other forms of scaffolding (second-semester students $5.8 \%$, fourth-semester students $3.8 \%$, and semester six students $0 \%$ ). Second, sequentially, the forms of scaffolding needed by respondents were modeling (30.8\%), learning instructions $(21.2 \%)$, questions to explore learning material (13.5\%), advice and reminding $(10.3 \%)$, problem-solving drive (5.8\%), feedback $(5.1 \%)$, and command to learn $(3.2 \%)$. Third, except for secondsemester students, learning instructions are the second form of scaffolding that most students need. Fourth, scaffolding in the form of " instructing " and "feedback" has a fixed tendency, namely the higher the semester level the more students do not need it: (1) scaffolding in the form of instructing, the second semester gets $5.8 \%$, the fourth semester $3.8 \%$, and sixth semester $0 \%(5.8>3.8>0)$; (2) second-semester feedback scaffolding $7.7 \%$, fourth semester $5.8 \%$, and sixth semester $1.7 \%(7.7>5.8>1.7)$. Fifth, fourth-semester students got the highest score for scaffolding in the form of suggesting $(13.5 \%)$ followed by sixth-semester students $(9.6 \%)$, and fourth-semester students $(7.7 \%)$. Sixth, the second-semester students needed questions in the form of scaffolding $(17.3 \%)$ than sixth-semester students $(13.5 \%)$ and fourth-semester students $(9.6 \%)$.

\section{A. The difference in millennial student scaffolding needs}

One of the results of this study is the difference in scaffolding needs between students based on semester level, especially between second and sixth-semester students. This result is being evidenced through descriptive and one-way ANOVA analysis. Descriptive analysis (Tableure 1) found that there were differences in average scores between the second semester, fourth semester, and sixth-semester students. There is a tendency that the higher the semester, the lower the average score for scaffolding needs. In other words, the higher the semester, the less scaffolding given. Furthermore, ANOVA's analysis found that there were significant differences in student scaffolding needs, wherein F-count (3.365) was greater than F-table (3.055). Through the post hoctest, significant differences were found between the second semester and sixth-semester students (Tableure 4). This means that the length of study in college affects the scaffolding that students need.

If it is assumed that the longer students study at higher education they are increasingly having SRL, then it is closely related to their need for scaffolding. Because learning independence enables students to control themselves, including controlling their learning environment [30]. According to Zimmerman \& Schunk and also includes the ability to plan, implement, monitor, and evaluate learning [31] [32]. They can set learning goals, manage the environment and learning time, self-instruct, monitor themselves, and strengthen themselves, and only seek help if needed [33] [34] [35]. Therefore, for the scaffolding is of course reduced or in accordance with what they need. In other words, scaffolding (only) is given to students who do not have SRL, especially in teaching procedural skills [12].

According to Vygotsky scaffolding aims to achieve ZPD (Zona of Proximal Development) conditions [14]; or guide student self-learning [15], and achieve learning success [16]. Thus scaffolding is more urgent given to students who do not have prior knowledge and have low academic achievement [11].

\section{B. Millennial Student Scaffolding Needs}

The results of this study reveal that although millennial students learn with many learning resources, including sources of learning the internet (google), they still need scaffolding. This answers the problems found in Hsieh, Lee, and $\mathrm{Su}$ in millennial generations, namely learning control, learning disorientation, and cognitive load. The three dominant forms of scaffolding that students need are modeling, learning instructions, and questions to explore learning material [2]. In accordance with the problems found in Hsieh, Lee, and Su the scaffolding first aims for the learner millennial to have a clear learning orientation and control their learning to achieve the expected learning goals [2].

Scaffolding is believed to solve student learning problems. Roschelle, et al found that students who were given scaffolding in the form of feedback can solve learning problems better [36]. The indicators shown are the participation of students to ask, explain, and discuss problem-solving. Correspondingly, research conducted by Belland, Glazewski, and Richardson found that scaffolding can support students' development of argumentation abilities [13]. Simons and Klein conducted 
research on three subject groups (group that were required to be given scaffolding, group that were given the choice of using or not using scaffolding, and group that were not given the choice to use scaffolding) obtained the results that group that were required to be given scaffolding obtained posttest scores higher than the other two groups [37]. Although it did not find a convincing effect from the implementation of scaffolding on student performance (both group and individually on the knowledge domain), Molenaar, et al still found that scaffolding has an impact on individual metacognitive and knowledge transfer [38].

The many forms of scaffolding needed by millennial students, as found in this study, reveal that teachers and lecturers need to analyze student characteristics (including learning needs), analysis of learning content, strategies and media used in learning. Thus the form of scaffolding that is applied in learning activities is effective in achieving the desired learning goals. The results research of Azevedo and Jacobson on hypertext and hypermedia found that the use of scaffolding can help foster student learning [39]. To achieve this goal they suggest that learning must be carefully designed, both the type, amount, and delivery techniques, as well as important considerations such as learning level, level of student development, prior knowledge of students, and learning content [39]. Thus it can be emphasized that the effectiveness of the use of scaffolding needs to consider aspects of learning such as learning needs, SRL, prior knowledge, the level of student development, characteristics and level of difficulty of the subject matter, etc.

Scaffolding given to students who do not have SRL and low intelligence is considered more urgent and meaningful. Research conducted by Thomas and Philpot on the use of inverted classroom strategies shows that there is no significant difference in learning outcomes between students in the inverted class (experimental class) and conventional class (control class) [6]. This was suspected because students were not given scaffolding about how they did learning activities before class. Therefore the ability to give scaffolding to students is a skill that every educator must possess. The ability of teachers (and lecturers) to provide scaffolding to students is an important competence in online learning [26].

In the era of online learning, scaffolding can be given by a teacher or lecturer, parents, peer in the form of a computer-based or paper-based tool that allows students to participate meaningfully in learning and experience increased skills in tasks that they cannot achieve independently [17] [20]. This is very necessary, especially in online learning as revealed in the study of Wang, et al [21]. In the context of online learning, study guides in SRL are very important for knowledge maps, discussions, questions and answers about the concept of knowledge, and online chat for conceptual understanding and content [21]. Expert guidance in the form of road maps and strategies given to student learning environments can help them understand the discipline of the investigation process [22].

Online learning and blended learning in the internet generation will be effective and efficient if supported by the use of appropriate scaffolding forms. Cause online and blended learning requires learning assistance from other parties so that students do not experience disorientation and cognitive load when doing learning activities [2] [26]. Scaffolding given to online learning sessions can be in the form of a questionnaire, worksheet [25], instructions, feedback, instruct [17].

\section{CONCLUSION}

There are significant differences in the needs of millennial students scaffolding in the Indonesian language education study program STKIP Santu Paulus Flores Indonesia. This is evidenced by one-way ANOVA analysis $(\mathrm{F}=3.365, \mathrm{df}=2,153$, $\mathrm{P}=0.037$ ). Through the post hoc test, differences in scaffolding needs mainly occur between first and sixth-semester students ( $\mathrm{P}$ $=0.037$ ).

The higher the semester (length of study in college) the more students do not need scaffolding. Although one-way ANOVA analysis does not show significant differences in scaffolding needs between second and fourth-semester students $(\mathrm{P}=0.457)$ and fourth and sixth-semester students $(\mathrm{P}=0.410)$, but the average score of the three student groups is different and/or decreases (semester $2=33.42$, semester $4=32.58$, and semester $6=31.67$ ) along with the longer they study in college.

Almost all forms of scaffolding are needed by millennial students of the Indonesian Language Education Study Program STKIP Santu Paulus Flores Indonesia although the level of urgency is different. Through descriptive statistics (Tableure 5), obtained sequence of scaffolding needs is as follows: modeling $(30.8 \%)$, hints $(21.2 \%)$, questions to explore learning material $(13.5 \%)$, suggestions and reminders $(10,3 \%)$, problem-solving encouragement $(5.8 \%)$, feedback $(5.1 \%)$, and instructing $(3.2 \%)$.

For further research: a) it is necessary to experiment about differences in millennial student scaffolding needs, both in the context of college, high/middle, dan elementary schools; b) it is necessary to experiment about the urgency of scaffolding forms for millennial students, both in college, high/middle, dan elementary schools.

Need to use needs-based forms of scaffolding. The use of a form of scaffolding that suits learning needs is expected to achieve the expected learning goals. Before using scaffolding in learning activities it is necessary to analyze learning, especially related to student learning needs, learning strategies, and learning resources and media to be used 


\section{ACKNOWLEDGMENT}

We thank you to all those who helped us in producing this article. Especially, we would like to thank: (a) the foundation assisted Paul Ruteng who has funded the publication of this article and the publisher who is willing to publish it; (b) Chairperson of the Indonesian Language Education Study Program STKIP Saint Paul Ruteng Flores, who has allowed us to carry out research; and (c) State University of Malang which always encourages us to produce scientific works.

\section{REFERENCES}

[1] Millćević,-K. A., Vesin, B., Ivanović, M., Budimac, Z., \& Jain, C.L. (2017). E-Learning Systems Intelligent Techniques for Personalization. Switzerland: Springer.

[2] Hsieh, T.-C., Lee, M.-C., \& Su, C.-Y. (2013). Designing and Implementing a personalized remedial learning system for enhancing the programming learning. Educational Technology \& Society, 16 (4), 32-46.

[3] Pletka, B., (2007). Education The Net Generation, How To Engage Students In The 21st Century. United States: Santa Monika Press LIC.

[4] Kamdi, W. (3 Maret 2018). Pendidikan Tingggi 4.0. Kompas, p.4.

[5] DiLullo, C., McGee, P., \& Kriebel, M.R. (2011). Demystifying the millennial student: a reassessment in measures of character and engagement in professional education. Anatomical Sciences Education, 4, 214-226.

[6] Thomas, S.J. \& Philpot, A. T. (2012). An inverted classroom model for the mechanics of the material course. American Society for Engeneering Engineering education (ful paparpaper). URL: www.asee.org/.../2012_ASEE_-_Final_-_An_Inverted

Classroom_Model_for_a_Mec.. (online), 12 Maret 2018 .

[7] Morris, R, Hadwin, A.F, Gress, C.L, Z., Miller, M., Fior, M., Church, H., \& Winne, P.H. (2010). Designing roles, scripts, and prompts to support CSCL in the study. Computers in Human Behavior, 26 (5), 815-824.

[8] Gannod, G. C., Janet, B. E., \& Michael, H.T. (2008). Using the inverted classroom to teach software engineering. ICSE'08 Preceeding Proceeding of The 30th International Conferences on Software Engineering May 10 18, Leipzig, Germany, 777-786.

[9] Nugroho, A.S. (2016). "Big Data, Artificial Intelligent And Education, Paper presented at the National Seminar September 242016 at the State University of Malang East Jawa Indonesia.

[10] Richard, G. M. Jr. (2011). Adapting teaching to the millennial generation: a case study of a blended/hybrid course. International CHRIE Conference-Refereed Track, July 28, 1-7.

[11] Raes, A., Schellens, T., Wever, B.De., Vanderhoven, E. (2012). Scaffolding information problem problem-solving in web-based collaborative inquiry Learninglearning. Computers \& Education, 59 (1), 82-94.

[12] Bannert, M. (2009). Promoting self-regulated learning through prompts. Zeitschrift Fur Padagogische Psychologie, 23 (2), 139-145.

[13] Belland, R.B., Glazewski, D.K., \& Richardson, C.J. (2011). Problembased learning and argumentation: testing a scaffolding framework to support middle school students' creation of evidence-based arguments. Instructional Science, 39 (5), 667-694

[14] Hogan, K., \& Pressley, M. (1997). Scaffolding Student Learning: Instructional Approaches And Issues. Cambridge MA: Brookline Books.

[15] Wecker, C., \& Fischer, F. (2010). Fading instructional scripts: preventing relapses into novice strategies by distributed monitoring. In K. Gomez, L. Lyons, \& J. Radinsky (Eds.), Learning in the disciplinesDisciplines: Proceedings of the 9th international conference of the learning sciences
(ICLS), 1. Chicago IL: International Society of the Learning Sciences, Full Papers.

[16] Davis, E. A., \& Miyake, N. (2004). Explorations of scaffolding in complex classroom systems. Journal of the Learning Sciences, 13 (3), 265-272.

[17] Belland, R. B. (2012). Habitus, scaffolding, and problem-based learning: why teachers' experiences as students matter. In S.B Fee B.S., \& Belland R.B. (Eds.). The Role of Criticism in Understanding Problem Solving, Explorations in the Learning Sciences, Instructional Systems and Performance Technologies (pp.87-100). Utah State University: Springer.

[18] Lu, J., Lajoie, P.S., \& Wiseman, J. (2010). Scaffolding problem-based learning with CSCL tools. Computer-Supported Collaborative Learning, 5, Springer: 283-298.

[19] Anghileri, J. (2006). Scaffolding practices that enhance mathematics learning. Journal of Mathematics Teacher Education, 9, 33-52.

[20] Belland, R. B. (2014). Scaffolding: defenitiondefinition, current debate, and future direction. In Spector, M.J., Merrill, D.M., Elen, J., \& Bishop, J. M. (Eds.), Handbook of Research on Educational Communications and Technology (Fourth Edition), (pp. 505-518). AECT-New York: Springer.

[21] Wang, M., Peng, J., Cheng, B., Zhou, H., \& Liu, J. (2011). Knowledge visualization for self-regulated learning. Educational Technology \& Society, 14 (3), 28-42.

[22] Saye, J. W., \& Brush, T. (2002). Scaffolding critical reasoning about the history and social issues in multimedia-supported learning environments. Educational Technology Research and Development, 50 (3), 77-96.

[23] Davis, C. (2013). Flipped or inverted learning: strategies for course design. In E. Smyth, \& J. Volker (Eds.), Enhancing Instruction with Visual Media: Utilizing Video and Lecture Capture (pp. 241-265) Hershey, PA: IGI Global.

[24] Talbert, R. (2014). Inverting the linear algebra classroom. PRIMUS, 24 (5), 361-374.

[25] Handke, J. (2016). The inverted classroom mastery model - a diary study. In Handke, J., Kiesler, N., Wiemeyer, L. (Eds.), The Inverted Classroom Model (The 2nd German ICM-Conference - Proceedings, (pp.15-34

[26] Dabbagh, N. (2003). Scaffolding: an important teacher competency in online learning. Tech Trend, 47 (2), 39-44.

[27] Latan, H. (2014). Aplikasi Analisis Data Statistik Untuk Ilmu Sosial Sains Dengan IBM SPSS. Bandung: Alfabeta.

[28] Pallant, J. 2005. SPSS Survival Manual. Sydney: Allen \& Unwin.

[29] Bandur, A. (2013). Penelitian Kuantitatif Desain dan Analisis Data Dengan SPSS. Yogyakarta: Deepublish.

[30] Vassallo, S. (2013). Critical pedagogy and neoliberalism: concerns with teaching self-regulated learning. Studies in Philosophy and Education, 32 (6), 563-580.

[31] Zimmerman, B. J., \& Schunk, D. H. (1998). Self-regulated Learning: From Teaching to Self-Reflective Practice: New York: Guilford

[32] Chen, C. S. (2002). Self-regulated learning strategies and achievement in an introduction to information system course. Information Technology, Learning, and Performance Journal, 20 (1), 11-25.

[33] Cazan, A. M. (2014). self-regulated learning and academic achievemen in the context of online learning environments. The 10th Internastional Scientific Conference eLearning and Software for education Bucharest, April 24-24, 90-95.

[34] Shih, K.-P., Chen, H.-C., Chang, C.-Y., \& Kao, T.-C. (2010). The development and implementation of a scaffolding-based self-regulated learning system for e/m-learning. Educational Technology \& Society, 13 (1), 80-93.

[35] Maftoon, P. (2014). Using self-regulation to enhance efl learners' reading comprehension. Journal of Language Teaching and Research, 5 (4), 844 855 . 
[36] Roschelle, J., Rafanan, K., Bhanot, R., Estrella, G., Penuel, B., Nussbaum, M., \& Claro, S. (2010). Scaffolding group explanation and feedback with handheld technology: impact on students' mathematics learning. Education Technology Research Development, 58 (4), Springer-Verlag: 399-419.

[37] Simons, K. D. \& Klein, J. D. (2007). The impact of scaffolding and student achievement levels in a problem-based learning environment. Instructional Science, 35 (1), 41-72
[38] Molenaar, I., Boxtel, C.A.M.v., \& Sleegers, P.J.C. (2011). Metacognitive scaffolding in an innovative learning arrangement. Instructional Science, 39, 785-801.

[39] Azevedo, R., \& Jacobson, M. J. (2008). Advances in scaffolding learning with hypertext and hypermedia: a summary and critical analysis. Education Technology Research Development, 56 (1), 93-100 